\title{
Pattern of Public and Private Capital Formation in Agriculture in Karnataka, India
}

\author{
K. Shruthi*, Amrutha T. Joshi, G.M. Hiremath and Suresh S. Patil
}

Department of Agricultural Economics, University of Agricultural Sciences, Raichur, India

*Corresponding author

\section{Keywords \\ Food Security, Capital, Capital formation, Public investment and Private investment \\ Article Info \\ Accepted: 26 July 2018 Available Online: 10 August 2018}

\section{A B S T R A C T}

\section{Introduction}

Agriculture sector in India has demonstrated an admirable performance over the past four decades but still there is abundant scope to improve for occupying the premier position in the global market. Agriculture is not only a source of livelihood but also a way of life. In the years of planning, the policy makers had attempted to give a due focus to the primary sector. The experience of developed countries had shown that agricultural development has helped to a greater extent in the process of their industrialization. It is seen that increased agricultural output and productivity tend to contribute substantially to an overall economic development of a predominantly agricultural and over populated country. Increase in agricultural productivity has made substantial contributions to the economic development of a country. 
The most important pre-requisite in the agricultural sector is the need to encourage farmers to make long term investment. High investments contribute to higher growth in production and income, mitigation of poverty and enhanced food security, both at the national and household levels. Capital, be it in physical or human form, greatly contributes towards increasing the efficacy of the productive effort (Schultz, 1964). Capital Formation assumes paramount importance in the context of policy making by the State and Central Governments. It acts as an indicator in the measurement of economic growth of State. It reveals the potentiality of the investment in the public as well as the private sectors and gives net addition to the assets created during the year. This is more important in agriculture with view that, task of increasing production to keep pace with the increase in population against the odds of the vagaries of monsoon. This paper studies the capital formation in agriculture at state level (Karnataka) during recent two decades.

Inevitably, public support is required not only through an increased flow of credit and creation of infrastructural investments but also through the productive investment in agriculture across its various head components. There is ample evidence to show that rural infrastructural investments have contributed immensely to increased agriculture productivity across many developing countries (Ravallion and Datt, 2002; Mogues et al., 2012), which have, in turn, enabled the mitigation of poverty in the long run (Syed and Miyazako, 2013). However, the literature indicated that high investments have significantly contributed to higher production and growth in almost every developing country, including India (Fan, 2008; Mogues et al., 2015).

In particular, the impact of public investments and input subsidy in accelerating agricultural productivity and subsequently, in lessening rural poverty and food insecurity at both national and household levels is well documented (Ravallion and Datt, 2002; Fan et al., 2008; Syed and Miyazako, 2013). Capital formation assumes a greater significance in view of need for infusing newer capital in agriculture. Hence, the state provides all kinds of support and encouragement to farmers to enhance capital formation both at micro and macro levels. At micro level, the state supports capital formation by way of subsidies, credit, technology and extension service. At macro level, all states undertake direct investment for creating infrastructural facilities which are expected to have complementary effect on capital formation at individual farms.

In the present study, an attempt has been made to analyze the pattern of public and private capital formation in Karnataka. Public capital is pumped into the state through various capital heads. It is also vital at this juncture to analyse the private investment pattern of the state as farmers in many parts of the state keep on improving their farms with through investment on various farm assets.

\section{Materials and Methods}

The study is confined to the state of Karnataka. The present paper is based on secondary data on public and private capital formation in agriculture which were collected from various authenticated sources. Since the data on state level public capital formation in agriculture is not available, the capital expenditure from the government was considered as the capital investment in the state, with the assumption that the total capital expenditure would be utilized in state which resulted in capital formation. This consideration was based on the past studies conducted on same criterion (Baba et al., 2010; Singh, 2015). 
The revised estimates of capital expenditure for agriculture and allied sectors in Karnataka were obtained from State Finances: A Study of Budgets, RBI from 1992-93 to 2015-16. Data on state level private investment in agriculture has been obtained from Household Capital Expenditure in India for the benchmark years of 1991-92, 2002-03 and 2012-13 from reports of All India Debt and Investment Survey (AIDIS) by NSSO. The AIDIS survey is conducted periodically at decennial intervals. Thus, the decadal composition of private capital investment across different component heads over three decades are presented in results, as per the availability of household survey reports of NSSO.

Tabular presentation was adopted for representing the collected data on public and private capital formation in agriculture. The data were compared and contrasted with the aid of averages, percentage etc. to obtain meaningful results.

\section{Results and Discussion}

\section{Magnitude of public capital formation in agriculture}

An overview of public capital formation in agriculture at the macro level (Karnataka) is needed to get an idea regarding the government investment pattern in agriculture and irrigation systems. Thus, the public capital expenditure under different component heads has been presented in Table 1 . Agriculture development policies and programmes in the recent decades had huge investments to make best use of irrigation. Thus, public capital formation in agriculture also includes investment on minor, medium and major irrigation and flood control systems. The public expenditure on irrigation systems has been increased from ₹5.17 billion in 1992-93 to ₹ 97.44 billion in 2016-17. This was due to recognizable fact that, the state has implemented many irrigation development projects like Tungabhadra, Upper tunga, Bhadra Ghataprabha, Upper Krishna stage I and II, Singatlur etc. The impact of investment on irrigation systems can be envisaged with the increase in net irrigated area in the state from 2.13 mha in 1990-91 to 4.12 mha in 2016-17 (Anonymous, 2015).

The total investment share among the components of agriculture and allied activities was concentrated on different heads in each decade. During 1992-93, the crunch share of 53.69 per cent of the total agricultural investment was for co-operation followed by fisheries, crop husbandry and so on. The prime importance given for co-operatives during that period was because; it was an extended era of co-operative finance in Indian agriculture. Wherein, there was more concern about the credit advancement to farmers with lower interest rates through co-operative banks (Reddy and Ram, 1996). In addition, Phase III of Operation Flood (1987-1996) consolidated India's dairy co-operative movement by adding 69,600 new dairy cooperative societies and thereby covering 90 lakhs milk producer members (Basavaraj, 2003). The ministry of environment and forests initiated a central scheme of aforestation and eco-development in 2001-02 under forest department agencies to gradually cover 0.175 million villages situated close to forests (Mukerji, 2003). Thus, during the beginning of 2002-03, forestry and wild life has received more attention in terms of fund flow (₹ 104.6 million)

In recent times (2012-13 and 2016-17), the public funds has concentrated on crop husbandry, animal husbandry and dairy development and fisheries. Karnataka ranks $11^{\text {th }}$ in overall milk production in the country and the second largest milk producer in the cooperative sector after Gujarat. Dairying and 
fisheries has become an important secondary source of income for millions of rural families and has assumed the most important role in providing employment and income generating opportunities particularly for marginal and women farmers. Thus, the major share of total investment has been centralized on these important components.

\section{Magnitude of private capital formation in agriculture}

Private investment in agriculture included the investment made by the farm households across different capital heads. Unlike the study of public capital formation in agriculture in Karnataka, the private capital formation in agriculture and share on its components was also assessed (Table 2). The decadal percentage change between the decades 1992-93 and 2003-04 (A to B), 200304 and 2013-14 (B to C) and the overall percentage change between 1992-93 and 2013-14 (C to A) were worked out to get the bird's eye view of the changes that took place in each capital heads of the farm household investment in agriculture in Karnataka. The total private capital formation in agriculture in Karnataka has increased from `362.5 million in 1992-93 to `8765.3 million in 2013-14.

Major expenditure during 1992-93 was on transport equipments ( 204.9 million) followed by improvement/ reclamation of land amounting ` 194.5 million and wells and irrigation resources ('114.4 million). The other components like agricultural machinery, others, livestock- as a fixed asset, farm houses/ buildings and orchards and plantations were in next descending orders of farm household investment.

During the next decade (2003-04), major increase over previous decade was observed in expenditure on agricultural machinery $(95.44 \%)$ among all assets. This change may be attributed to the benefits received by the farmers in Karnataka from subsidies of Farm Mechanization Scheme which was implemented in 2000-01. Wherein, the state has been receiving enough funds to improve mechanization which promoted the additional expenditure by farm households towards machineries.

In the recent times (2013-14), majority of investment was on wells and other irrigation resources i.e., ₹ 3456.8 million. The changes in expenditure on wells and irrigation resources in past two decades have an enthralling effect for the researchers. The increased expenditure towards wells and irrigation resources might be due to aspiration of increasing the production at the farm and to shift towards the commercial crops or be safe with the uncertain climatic situations or irrigation intensive crops to get higher income. Further, livestock, agricultural machinery and improvement/ reclamation of land have also received much attention in terms of more farm expenditure towards them. The increased public investment on animal husbandry and dairy development through various schemes had encouraged farmers to spend more on livestock.

\section{Comparison of public and private capital formation in agriculture}

It is imperative to know the share of public and private investment in total capital formation in agriculture in order to check the complementarity nature between them at the state level.

Table 3 presents the total capital formation in agriculture excluding irrigation (A) and including irrigation (B). Since the investment on irrigation systems was higher, the total capital formation in agriculture with irrigation was more than the total capital formation in agriculture without irrigation. 
Table.1 Composition of public capital formation in agriculture in Karnataka at current prices

\begin{tabular}{|c|c|c|c|c|c|c|c|c|c|}
\hline \multirow{2}{*}{$\begin{array}{c}\text { Sl. } \\
\text { no } \\
\text {. }\end{array}$} & \multirow[t]{2}{*}{ Particulars } & \multicolumn{2}{|c|}{$1992-93$} & \multicolumn{2}{|c|}{$2002-03$} & \multicolumn{2}{|c|}{$2012-13$} & \multicolumn{2}{|c|}{ 2016-17 } \\
\hline & & ₹ million & $\begin{array}{l}\% \text { to } \\
\text { total }\end{array}$ & ₹ million & $\begin{array}{l}\% \text { to } \\
\text { total }\end{array}$ & ₹ million & $\begin{array}{l}\% \text { to } \\
\text { total }\end{array}$ & ₹ million & $\begin{array}{l}\% \text { to } \\
\text { total }\end{array}$ \\
\hline I & Agriculture and allied activities & & & & & & & & \\
\hline 1 & Crop husbandry & 11.10 & 13.01 & 3.00 & 1.21 & 867.00 & 32.51 & 743.00 & 26.75 \\
\hline 2 & $\begin{array}{l}\text { Animal husbandry and dairy } \\
\text { development }\end{array}$ & 5.20 & 6.10 & 1.00 & 0.40 & 932.00 & 34.95 & 859.00 & 30.92 \\
\hline 3 & Fisheries & 14.60 & 17.12 & 45.80 & 18.48 & 612.00 & 22.95 & 812.00 & 29.23 \\
\hline 4 & Forestry and wild life & 6.60 & 7.74 & 104.60 & 42.19 & 186.00 & 6.97 & 274.00 & 9.86 \\
\hline 5 & Food storage and warehousing & 2.00 & 2.34 & 53.00 & 21.38 & 50.00 & 1.87 & 80.00 & 2.88 \\
\hline 6 & Co-operation & 45.80 & 53.69 & 40.50 & 16.34 & 20.00 & 0.75 & 10.00 & 0.36 \\
\hline & Total & 85.30 & 100.00 & 247.90 & 100.00 & 2667.00 & 100.00 & 2778.00 & 100.00 \\
\hline II & Irrigation systems & $\begin{array}{r}5172.1 \\
0\end{array}$ & - & $\begin{array}{r}18727.0 \\
0\end{array}$ & - & $\begin{array}{r}56014.0 \\
0\end{array}$ & - & $\begin{array}{r}97446.0 \\
0\end{array}$ & - \\
\hline
\end{tabular}

Source: State finances, RBI 
Table. 2 Composition of private capital formation in agriculture in Karnataka at current prices

\begin{tabular}{|c|c|c|c|c|c|c|c|}
\hline \multirow{2}{*}{$\begin{array}{l}\text { Sl. } \\
\text { no. }\end{array}$} & \multirow[t]{2}{*}{ Particulars } & \multicolumn{3}{|c|}{ ₹ million } & \multirow{2}{*}{$\begin{array}{c}\text { \% change from } \mathrm{B} \\
\text { to } \mathrm{A}\end{array}$} & \multirow{2}{*}{$\begin{array}{c}\text { \% change from } \mathrm{C} \\
\text { to } \mathrm{B}\end{array}$} & \multirow{2}{*}{$\begin{array}{c}\% \\
\text { change } \\
\text { from } \mathrm{C} \\
\text { to } \mathrm{A}\end{array}$} \\
\hline & & $\begin{array}{l}1992-93 \\
\text { (A) }\end{array}$ & $\begin{array}{l}\text { 2003-04 } \\
\text { (B) }\end{array}$ & $\begin{array}{l}\text { 2013-14 } \\
\quad(\mathrm{C})\end{array}$ & & & \\
\hline 1 & $\begin{array}{l}\text { Improvement/ reclamation of } \\
\text { land }\end{array}$ & 194.50 & 125.80 & 721.00 & -35.32 & 473.13 & $\begin{array}{r}270.6 \\
9\end{array}$ \\
\hline 2 & Orchards and plantations & 10.60 & 6.20 & 25.20 & -41.51 & 306.45 & $\begin{array}{r}137.7 \\
4\end{array}$ \\
\hline 3 & $\begin{array}{l}\text { Wells and other irrigation } \\
\text { resources }\end{array}$ & 114.40 & 214.20 & 3456.80 & 87.24 & 1513.82 & $\begin{array}{r}2921 . \\
68\end{array}$ \\
\hline 4 & Livestock used as fixed asset & 32.40 & 55.90 & 2566.10 & 72.53 & 4490.52 & $\begin{array}{r}7820 . \\
06\end{array}$ \\
\hline 5 & Agricultural machinery & 98.60 & 192.70 & 896.90 & 95.44 & 365.44 & $\begin{array}{r}809.6 \\
3\end{array}$ \\
\hline 6 & Transport equipment & 204.90 & 105.70 & 1084.00 & -48.41 & 925.54 & $\begin{array}{r}429.0 \\
4\end{array}$ \\
\hline 7 & Farm houses/ buildings & 15.30 & 6.00 & 4.10 & -60.78 & -31.67 & -73.20 \\
\hline 8 & Others & 91.80 & 26.00 & 11.20 & -71.68 & -56.92 & -87.80 \\
\hline & Total farm expenditure & 362.50 & 732.50 & 8765.30 & 102.07 & 1096.63 & $\begin{array}{r}2318 . \\
01\end{array}$ \\
\hline
\end{tabular}

Source: Household capital expenditure survey, AIDIS, NSSO reports 
Table.3 Public and private capital formation in agriculture in Karnataka at current prices

\begin{tabular}{|c|c|c|c|c|c|c|}
\hline \multirow[t]{2}{*}{ Year } & \multicolumn{3}{|c|}{ Public capital formation in } & \multirow{2}{*}{$\begin{array}{c}\text { Private } \\
\text { capital } \\
\text { formation }\end{array}$} & \multirow[b]{2}{*}{$\begin{array}{c}\text { Total } \\
\text { capital } \\
\text { formation } \\
\text { (without } \\
\text { irrigation } \\
\text { systems) }\end{array}$} & \multirow[b]{2}{*}{$\begin{array}{c}\text { Total } \\
\text { capital } \\
\text { formation } \\
\text { (with } \\
\text { irrigation } \\
\text { systems) }\end{array}$} \\
\hline & Agriculture and allied & Irrigation systems & Total & & & \\
\hline 1992-93 & $\begin{array}{r}85.30 \\
(19.05)\end{array}$ & 5172.10 & 5257.40 & $\begin{array}{l}362.50 \\
(80.95)\end{array}$ & $\begin{array}{r}447.80 \\
(100.00)\end{array}$ & 5619.90 \\
\hline 2003-04 & $\begin{array}{l}313.50 \\
(29.97)\end{array}$ & 22808.90 & 23122.40 & $\begin{array}{r}732.50 \\
(70.03)\end{array}$ & $\begin{array}{l}1046.00 \\
(100.00)\end{array}$ & 23854.90 \\
\hline 2013-14 & $\begin{array}{r}2835.00 \\
(24.43)\end{array}$ & 60967.60 & 63802.60 & $\begin{array}{r}8765.30 \\
(75.56)\end{array}$ & $\begin{array}{r}11600.30 \\
(100.00)\end{array}$ & 72567.90 \\
\hline 2016-17 & 2778.00 & 97446.00 & 100224.00 & - & - & - \\
\hline
\end{tabular}

Note: Figures in the parentheses indicates the percentage to the total capital formation (without irrigation systems)

Fig.1 Sector wise capital formation in agriculture in Karnataka

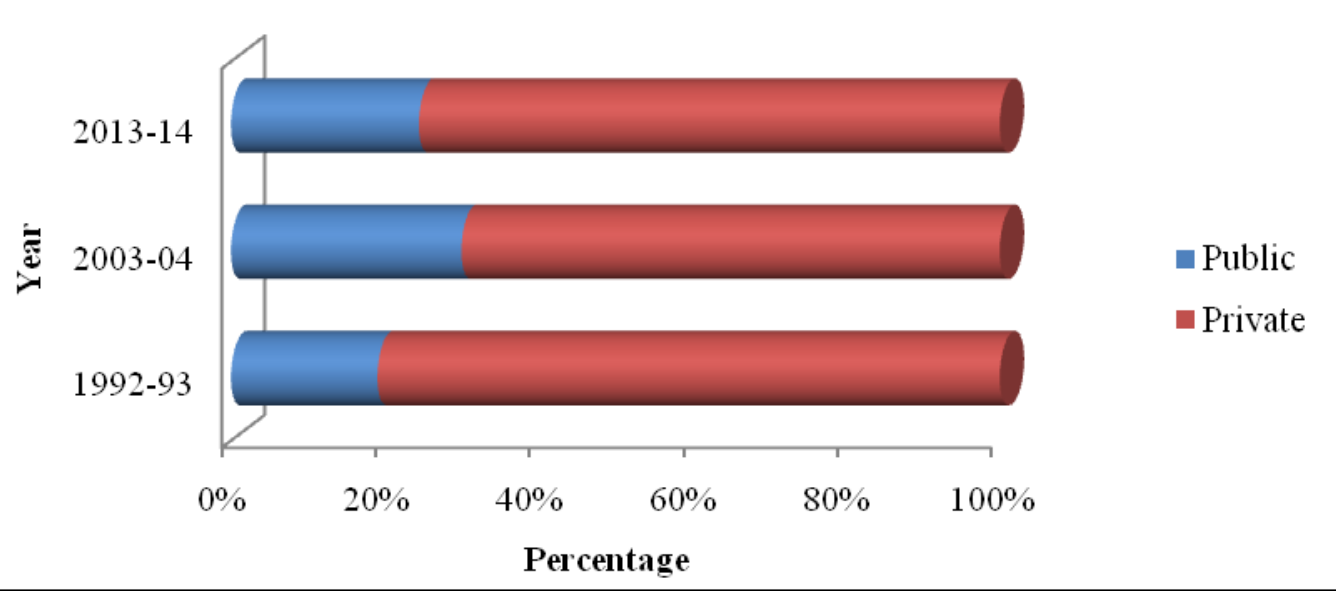


Further, form Figure 1, it was noted that, the share of private investment in total capital formation in agriculture was higher as compared to the share of public capital formation in agriculture (without irrigation systems) during all decades of study. However, increase in share of public capital expenditure was observed from 19.05 per cent in 1993-94 to 29.97 per cent in 2003-04. Whereas, private investment had contributed 80.95 per cent and 70.03 per cent to total capital formation in agriculture during the decades 1992-93 and 2003-04, respectively. In recent times (2013-14), public and private sectors had 24.43 per cent and 75.57 per cent share in total capital formation in agriculture.

In conclusion, capital formation in agriculture is a crucial component of growth and development in agriculture. Hence, it is a priority issue and much debated one by researchers and policy makers. The study assessed the magnitude of public and private capital formation in agriculture in Karnataka. An assessment was made on the quantum of both public and private investment to know the investment across various capital heads; an effort has been made to visualize the complementarity of publics' investment on investment made by farmers which were enumerated in the study by compiling data from different secondary sources.

It was found from the study that the total public and private capital expenditure on various heads of agriculture and allied activities has been increasing over the period of study. Public expenditure on irrigation systems which includes minor, medium, major and flood control systems had huge investment as compared to public investment on agriculture and allied activities. Animal husbandry and dairy development, crop husbandry and fisheries were the major component heads which received higher share in public expenditure during recent times
(2016-17). Among the components of private investment, wells and other irrigation sources, livestock, transport equipment and agricultural machineries were the major capital heads on which farmers were concentrated their expenditure during recent times (2013-14).

Thus, the total capital formation in agriculture had the maximum share from private capital formation in agriculture as compared to public capital formation in agriculture without irrigation systems. This trend in investment over time represents the increase capital formation in agriculture at the farm household level. Hence, same tempo needs to be maintained with the enhancement of public private partnerships. It was suggested from the study that, the public investment pattern in both agriculture and irrigation needs to be sustained by timely restructuring of allocation across the component heads with the view of improving the farm household investment.

\section{References}

Anonymous, Indian agricultural statistics. www.indiastat.com, 2015.

Baba SH, Saini AS, Sharma KD and Thakur DR, Impact of investment on agricultural growth and rural development in Himachal Pradesh: Dynamics of public and private investment. Indian Journal of Agricultural Economics, 2010, 65(1): 136-158.

Basavaraj SB, Milk producers' co-operative societies in Karnataka. Kurukshetra, 2003, 51(6): 23-26.

Fan S, Public expenditures, growth and poverty: lessons from developing countries. Oxford University Press, New Delhi, 2008.

Fan S, Gulati A and Thorat SK, Investment, subsidies, and pro-poor growth in rural India. Agricultural Economics, 2008, 39 
(2), 163-170.

Mogues T, Fan S and Benin S, Public investments in and for agriculture. The European Journal of Development Research, 2015, 27, 337-352.

Mukerji AK, Forest policy reforms in IndiaEvolution of the joint forest joint forest management approach. FAO publications, 2003.

Ravallion $\mathrm{M}$ and Datt $\mathrm{G}$, Why has economic growth been more pro-poor in some states of India than others? Journal of Development Economics, 2002, 68, 381-400.

Reddy SS and Ram RP, Agricultural finance and management. Oxford and IBH publishing Co. Pvt. Lt., 1996.

Schultz T, Transforming Traditional Agriculture, New Haven and London: Yale University Press, 1964.

Singh P, Complimentarity between public and private capital formation in agriculture in Uttar Pradesh. Journal of Progressive Agriculture, 2015, 6(2):5260.

Syed $\mathrm{S}$ and Miyazako M, Promoting investment in agriculture for increased production and productivity, Food and Agriculture Organization, Rome, 2013.

\section{How to cite this article:}

Shruthi, K., Amrutha T. Joshi, G.M. Hiremath and Suresh S. Patil 2018. Pattern of Public and Private Capital Formation in Agriculture in Karnataka, India. Int.J.Curr.Microbiol.App.Sci. 7(08): 4469-4477. doi: https://doi.org/10.20546/ijcmas.2018.708.473 